\title{
DEN KINESISKE DRØM OM HARVARD
}

\section{SUSANNE BREGNB/EK}

Det første, Xiao Piao spurgte mig om, da jeg mødte hende foran den vestlige indgang til Beijing Universitetet en kold vinterdag i 2005, var „Er du amerikaner? Er du fra et berømt amerikansk universitet?" Xiao Piao talte hurtigt og energisk med en amerikansk accent. Hun smilede anstrengt og virkede lettere skuffet, da jeg forklarede, at jeg ikke var fra et berømt amerikansk universitet, men at jeg var dansker, og at jeg kom fra Københavns Universitet, som hun aldrig havde hørt om. Men hun fortsatte med at sige, at hun var glad for at have muligheden for at udvikle sit engelsk, da hun var ved at forberede sig til den forhadte TOEFLprøve, som er nødvendig for at blive accepteret ved et udenlandsk universitet, gerne Harvard. Hun tog hurtigt initiativet og ledte vejen til en restaurant over for campus, og ret kort efter, at vi havde sat os ned med en skål dampende nudler foran os, begyndte hun at græde. Hun slog over i kinesisk og fortalte, at hun havde svært ved at leve op til sine forældres forventninger. Hendes forældre er akademikere fra Beijing, inden for hver sit naturvidenskabelige felt, og hun fortalte, at hendes bedstefar var en berømt forsker. Selv læste hun biologi, et fag, hendes forældre havde valgt.

Xiao Piao var en blandt mange unge mennesker, jeg mødte i løbet af 10 måneders feltarbejde på de to eliteuniversiteter i Beijing, Tsinghua Universitetet og Beijing Universitetet i 2005 og 2007, der havde svært ved at leve op til deres forældres forventninger til dem, gerne et stipendium til Harvard. Da jeg et stykke inde $\mathrm{i}$ feltarbejdet blev rådet til at skrive en besked på universiteternes intranetportaler (BBS), hvori jeg forklarede min interesse for at møde studerende og at høre om, hvordan de håndterede konkurrence, deres familierelationer og tanker om fremtiden, fik jeg en overvældende mængde henvendelser fra studerende, der gerne ville tale om deres liv og dele deres bekymringer. Med udgangspunkt $i$ to studerendes historier, Xiao Piao og Gu Wei, fra henholdsvis Beijing Universitet og Tsinghua Universitet, søger denne artikel at belyse, hvordan denne særlige 
gruppe kinesiske unge oplever og håndterer de høje forventninger til dem, der, som vi skal se, er modsætningsfyldte. Artiklen argumenterer for, at drømmen om Harvard i en vis forstand udgør både deres problem og den foreslåede løsning på deres problem og derved resulterer i en form for double-bind.

\section{Uddannelse og befolkningskvalitet}

Etbarnspolitikken, der blev indført under Deng Xiaoping i 1979, havde ikke blot til formål at nedbringe befolkningstallet, men også at forsøge at forbedre befolkningens kvalitet (suzhi). Etbarnspolitikken indebar en slags pagt imellem forældre og stat. Hvor forældre måtte begrænse sig til kun at have et barn, lovede staten til gengæld, at dette barn skulle vokse op og være sundt og højtuddannet, af høj kvalitet (Milwertz 1997). Antropologen Susan Greenhalgh har påpeget, at hvor reguleringen af befolkningens fertilitet var repressiv, var ideen om det perfekte enebarn særdeles attraktiv, og kinesiske forældre har været nødsaget til at acceptere begrænsningen af deres fertilitet og så i stedet at bruge alle deres ressourcer på at opbygge kvaliteten (suzhi) af dette ene barn (Greenhalgh 2003:217).

Begrebet „suzhi“ er vanskeligt at oversætte, og det dækker over utroligt mange modsætningsfyldte ideer og indgår i mange forskellige kontekster fra modsætningen imellem land og by, høj og lav, til børn og unges indre potentiale og nationens status vis-a-vis den øvrige verden. En udtømmende analyse af suzhi-diskursen er ikke mulig inden for rammerne af denne artikel, men jeg vil her fokusere på forholdet imellem uddannelse og begrebet befolkningskvalitet. Begrebet „suzhi“" oversættes gerne til ordet „kvalitet“, selv om det ikke helt fanger dets fulde betydning. Ifølge Andrew Kipnis har betydningen af begrebet ændret sig, siden 1979-udgaven af den autoritative kinesiske ordbog Sea of Words oversatte det som „en persons medfødte karakteristika“, hvorefter det på maoistisk vis tilføjedes, at disse er mindre afgørende end det sociale miljøs betydning for menneskelig udvikling (Kipnis 2006:297). Siden 1970'erne betoner begrebet ikke længere det naturlige i en natur-kultur-dikotomi. Selv om begrebet $\mathrm{i}$ dag refererer til internaliserede karakteristika hos enkelte individer, er de $i$ høj grad et resultat af opdragelse og uddannelse. Desuden betegner begrebet i moralsk forstand forskellen imellem høj og lav, og forøgelsen af suzhi er forbundet med nationens storhed (ibid.).

Siden 1980'erne er manglen på „kvalitet“ (suzhi) blevet brugt til at retfærdiggøre sociale hierarkier af enhver art og som forklaring på det, der har forhindret Kina i at opnå sin retmæssige plads i verden. ${ }^{1}$ Det ses ikke længere blot som et udtryk for den uuddannede landbefolknings tilbageståenhed, men er blevet det middel, hvorigennem middelklassen ser sig selv og forestiller sig vejen til social 
opstigning (Anagnost 2004). Begrebet omhandler de særlige karakteristika, der søges fremelsket hos børn og unge mennesker, så de kan udvikle sig til „kvalitetsindivider". Partiteoretikere, der beskæftiger sig med befolkningskvalitet, argumenterer for, at suzhi har tre komponenter: kropslig kvalitet, tankemæssig og moralsk kvalitet samt uddannelsesmæssig kvalitet. Ifølge Andrew Kipnis præger både konfucianistiske og marxistiske ideer om kultivering forståelsen af begrebet suzhi. Den holistiske form for udvikling, som begrebet indebærer, altså at der samtidig er tale om fysisk, intellektuel og moralsk dannelse, har rod i begge disse traditioner ${ }^{2}$ (Kipnis 2006:307).

Her kan suzhi måske bedst oversættes til det danske begreb „dannelse“ eller det tyske „Bildung“. I Distinction (1979) argumenterer Pierre Bourdieu for, at en marxistisk forståelse af klassebegrebet, der udelukkende baserer sig på forskellen imellem kapital og arbejde, er utilstrækkelig til at forstå sociale skel i et forbrugssamfund, hvor smag er et udtryk for social status (ibid.). I det urbane Kina bliver det unikke middelklassebarn opfostret, plejet og uddannet til at udvikle suzhi. Når migrantarbejdere søger til byerne for at opnå social opstigning, er de også på jagt efter suzhi ${ }^{3}$ (Jacka 2005). På denne måde er suzhi en arena, hvori klasseforskelle maskeres, og klassekampe kæmpes. Begrebet suzhi hænger sammen med en kamp for „væren“, som det bliver defineret symbolsk på et givent tidspunkt, eller det, Michel Foucault kalder epistemet eller sandhedsregimet (Foucault 1977). Disse drømme og håb om øget social status synes at være en spejling af fremkomsten af det europæiske borgerskab, som beskrevet af Herbert Marcuse i sit berømte essay Negations (1972). Borgerskabets dyrkelse af forfinelse, manerer og en indre sensibilitet blev set som modsætningen til bønder og primitive. På samme måde handler befolkningskvalitet i Kina altså ikke kun om at opnå akademiske grader, men om at udvikle sig til kvalitetsindivider, der har sunde kroppe, er kultiverede, har den rette smag og udvikler deres fulde (indre) potentiale (quanmian fazhan).

Samtidig med indførelsen af den åbne dørs politik i 1978, hvor Kina blev åbnet mod verden, genindførte Deng Xiaoping optagelsesprøverne til universitetet, der havde været afskaffet under Maos kulturrevolution (1966-1969), og uddannelse blev set som et vigtigt middel til at forbedre Kinas usikre plads i verden (Cherrington 1997; Fong 2004). Et af etbarnspolitikkens centrale slogans „Overlegen Fødsel, Overlegen Uddannelse“ viser tydeligt sammenhængen imellem begrænsningen af befolkningstallet og tanken om at hæve befolkningens kvalitet via blandt andet uddannelse. ${ }^{4}$

I de første år efter indførelsen af etbarnspolitikken blev enebørn sikret en plads på skoler af særlig høj kvalitet, men da nu langt størstedelen af børnene i kinesiske storbyer er enebørn, er konkurrencen om en plads ved de bedste ud- 
dannelsesinstitutioner accelereret, og et enkelt points forskel kan betyder radikalt forskellige livsmuligheder. Optagelsesprøverne er standardiserede over hele Kina og kræver en enorm mængde paratviden. Og selv for dem, der slipper igennem nåleøjet, fortsætter forventningspresset. Lad mig vende tilbage til Xiao Piao.

\section{Xiao Piao}

Xiao Piao forklarede, at hendes forældre altid havde ønsket, at hun skulle være den dygtigste i sin klasse. Derudover havde hun modtaget undervisning i engelsk, matematik og kalligrafi og klaver i weekenderne. Hun fortalte, at hun ofte havde skrevet af efter andre, og hun havde rettet i sine eksamenspapirer for at få dem til at se bedre ud, end de var. Det havde fået hendes forældre til at være stolte af hende, når hun kunne fremvise gode resultater, men bagefter havde hun skyldfølelse og følte sig ensom.

Xiao Piao gik på en elitekostskole i mellemskolen, og hun huskede det som en ensom tid. I weekenderne tog de fleste børn hjem til deres forældre, men hendes forældre havde travlt, og hun ønskede heller ikke at blive konfronteret med deres forventninger. Hun savnede dem, men foretrak alligevel at blive på skolen sammen med nogle få resterende elever.

Hun havde det på samme måde nu. På trods af at hendes forældre begge boede i Beijing, besøgte hun dem sjældent, fordi hun skammede sig over sine dårlige resultater. Hun tilbragte i stedet det meste af tiden med at studere. Som i så mange andre urbane højtuddannede middelklassefamilier ønskede hendes forældre, at hun skulle tage en overbygning ved et amerikansk universitet, gerne Harvard. Hun selv ville også gerne til udlandet, men hun sagde, at hun havde „en plan“. Hun ønskede at rejse så langt væk fra sine forældre som muligt, så hun ikke længere kunne mærke presset. „De vil have, at jeg skal være succesfuld, så jeg kan tjene en masse penge", sagde hun uden skyggen af ironi. Da jeg spurgte hende, om ikke også hendes forældre ønskede, at hun skulle have det godt, svarede hun, at de ikke vidste, at hun ikke var glad. „Jeg er god til at spille komedie“, sagde hun. I det hele taget skjulte hun sine følelser fra andre mennesker, sagde hun. Som Theresa Kuan har påpeget, mener jeg, at det er værd at bemærke, at det, der på overfladen kan ligne økonomisk nyttemaksimering i forholdet imellem forældre og børn, skal ses som et udtryk for kinesiske forældres forsøg på at opnå en grad af kontrol over en usikker fremtid og at sikre sig, at der bliver en plads til deres barn i samfundet (Kuan 2008)

Jeg forsøgte at opmuntre hende ved at sige, at det er hendes liv, og at selv om hun ikke får topkarakterer, vil der være en udvej. Men mine klodsede forsøg på at trøste hende, prellede af på hende. I stedet for fortalte hun mig, at hun havde 
udviklet gode måder at administrere sin tid på, og at det var det vigtigste. Hun vendte tilbage til sit engelsktalende og smilende jeg igen, og imens hun pakkede sammen, foreslog hun mig, at hun kunne introducere mig for nogle af sine medstuderende, nogle kønne piger, der var gode til engelsk, og som også var gode til at danse, tilføjede hun. Det var, som om hun syntes, at hun selv var en fiasko, men at hun da i det mindste kunne introducere mig for nogle andre, der var mere succesfulde end hende selv. Da jeg efterfølgende forsøgte at kontakte hende igen, svarede hun hverken på mine mails eller opkald. Jeg var bekymret for, hvordan det ville gå hende, hvis hun fortsatte ad samme kurs, tilsyneladende uden nogen form for refleksion eller distance til det overvældende krav, at hele hendes værd som menneske afhang af et stipendium til Harvard.

Hendes tilværelse var tilsyneladende en konstant jagt på hendes forældres anerkendelse og kærlighed. Der var ingen adskillelse imellem hendes forældres, samfundets og hendes egne idealer, og dermed oplevede hun sig selv som en fiasko. Den udvej, hun forestillede sig, var en form for eskapisme, at flygte længst muligt væk fra sine forældre.

I Kina er der en tiltagende opmærksomhed på unges psykiske problemer som resultat af pres og konkurrence, og der har været gentagne forsøg på at reformere det kinesiske uddannelsessystem på en sådan måde, at det rent faktisk formår at skabe kompetente og dannede samfundsborgere af høj „kvalitet“ (suzhi), ikke blot „testmaskiner“ (Kipnis 2007:389). I det følgende vil jeg beskrive forsøget på at rette op på, hvad der ses som manglerne i det kinesiske uddannelsessystem, såvel som forældres måde at opdrage deres børn på.

\section{Ideerne bag kvalitetsopbyggende uddannelse}

I 1991 udkom bogen Harvard Girl, der beskriver alle de skridt, en mor tog, for at opdrage sin datter „,videnskabeligt“", så hun kunne blive den første kinesiske studerende, der opnåede et fuldt stipendium til Harvard Universitet (Liu \& Xinwu 2000). På bogens omslag ses datteren, Liu Yiting, stolt fremvise sit optagelsesbrev til Harvard. Lius succes beskrives som et resultat af morens uddannelsesmæssige plan, som hun begyndte at implementere, før datteren blev født. Hun beskriver den kost, hun indtog, da hun ventede Liu Yiting, hvordan datteren blev udsat for et nøje tilrettelagt disciplinært regime, og bogens præmis er altså, at ethvert barn kan opnå et stipendium til Harvard, hvis blot det bliver opfostret på den rette måde. Lius mor beskriver den diæt, hun var på, da hun ventede sin datter, og da datteren er blevet født, bliver hun madet i bestemte intervaller. I løbet af hendes første år begynder moren at træne datterens hukommelse ved at udsætte hende for en masse små øvelser, og da datteren er 18 måneder gammel, lærer 
hun hende at recitere digte fra Tang-dynastiet. Hendes ,fritid“ er fordelt imellem fysisk aktivitet eller tilegnelse af diverse erfaringer, som udgør grundlaget for de stile, hun bliver sat til at skrive (ibid.).

Denne form for forældrestyring er siden blevet kritiseret voldsomt for at begrænse udviklingen af kinesiske børn og unges egne kompetencer. I 2001 udkom en anden populær opdragelsesmanual, Kvalitetsopbyggende uddannelse $i$ USA af Huang Quanyu, der også blev en bestseller. Denne bog er skrevet fra en fars perspektiv, og den beskriver hans erfaringer med at opfostre sin søn i USA. Hans motivation består i et ønske om at finde frem til de uddannelsesmæssige tiltag, der øger amerikanske børns kvalitet (suzhi) og gør amerikanere i stand til at opnå rigdom såvel som nobelpriser (Woronov 2007:41-2; Huang 2001). Han argumenterer for at, at fordi det amerikanske uddannelsessystem opfordrer til medbestemmelse, bliver den enkelte studerende „selvaktualiseret“, det vil sige realiserer sit indre potentiale, i modsætning til kinesiske børn, der blot lærer at tilegne sig paratviden og at efterleve bestemte „sociale roller“ (ibid.). Forskellen på de to opdragelsesmanualer, der viste sig at have stor markedsværdi, viser et bredere ideologisk skift fra det, der ofte betegnes som „testbaseret“ (yingshi jiaoyu) frem for „kvalitetsopbyggende“ (suzhi jiaoyu) uddannelse.

Både studerende, forældre og lærere udtrykker frustration over det kinesiske uddannelsessystem, som i høj grad bygger på udenadslære, der er nødvendig for at bestå eksaminer og komme op til det næste trin i uddannelsessystemet. Selv om suzhi betyder „kvalitet“, og ,jiaoyu“ betyder uddannelse, kan begrebet ikke oversættes til „kvalitetsuddannelse“ eller „kvaliteten af en given uddannelse“, for det omhandler ikke kvaliteten af uddannelsessystemet som sådan. „Suzhi jiaoyu“ skal derimod forstås som uddannelse, der har til hensigt at forbedre befolkningskvaliteten (Woronow 2007). Selv om ideerne bag kvalitetsopbyggende uddannelse langtfra er entydige, og måden, hvorpå de skal implementeres, langtfra er klar (Thøgersen 2002:217), er grundtanken, at det ikke er nok at kunne bestå eksaminer (Woronov 2007:40). Kvalitetsopbyggende uddannelse går ud på at reformere uddannelsessystemet således, at de studerende realiserer deres fulde (indre) potentiale (quanmian fazhan) i form af færdigheder, der kan omsættes i den virkelige verden uden for universitetet (ibid.).

Fascinationen af det amerikanske uddannelsessystem, med forestillingen om Harvard som det ypperste symbol på succes, bunder ifølge antropologen Terry Woronov i en fascination af Amerika som verdens førende økonomi og i amerikanernes evne til at vinde nobelpriser (Woronov 2007). Dette er også forbundet med Kinas bestræbelse på ikke blot at fungere som ophav til verdens industri, men at skabe borgere af høj kvalitet, der kan gøre Kina i stand til at indgå på lige fod som partnere $i$ et globalt videnssamfund. 
René Girard taler om „mimetic desire“ (1965), der indebærer ideen om, at begær eller ønsker ikke opstår ud af vores indre, men fra vores ønske om at ligne den anden, at have det, den anden har. Dette forekommer imellem personer, men kan også ses som et billede på det, der er på spil imellem nationer. I tråd med denne tanke udgør Harvard indbegrebet af uddannelsesmæssig prestige og dannelse, og Kina ønsker efter sin indtræden i WTO at skabe højtuddannede samfundsborgere, der har de samme kvaliteter, som man mener, at amerikanske studerende er i besiddelse af, og derfor vil kunne gøre sig gældende som lige parter i en global vidensøkonomi. Samtidig forekommer der tilsyneladende også tilsvarende modbevægelser, i og med at den vestlige verden er fascineret af den måde, hvorpå det kinesiske samfund i en periode på omkring 20 år har forandret sig fra at være et fattigt landbrugsland til at være verdens tredje største økonomi (Kleinman, Jao \& Biel 2007:2).

Der er altså en tæt forbindelse imellem enkelte individers kamp - her en generation af enebørn - og en global kamp om magt og prestige. I Kina er der en lang tradition for at se egne traditioner som en hindring for modernisering og fremskridt, og Kinas forhold til Vesten har rødder tilbage til Fjerde Maj-bevægelsen og det kinesiske oplysningsprojekt (Qi 2008:273). Her er det nødvendigt med yderligere historisk kontekstualisering.

Den kejserlige embedseksamen blev indført under Han-dynastiet (202 f.Kr. til 220 e.Kr.). Den dannede vejen til at opnå elitestatus under Song-dynastiet (9601279) og varede helt frem til 1905, hvor den blev afskaffet som en del af Qingdynastiets forsøg på reform (Fong 2004:101).

Det sidste kejserdømme faldt i 1911, og herefter forsøgte Japan og nogle europæiske nationer at kolonialisere Kina ved brug af militær magt (Qi 2008:257) I kølvandet fulgte antijapanske og antivestlige bevægelser. Men i 1919 kulminerede kinesiske intellektuelles ønske om reform af den hidtidige hierarkiske konfucianistiske samfundsorden med Fjerde Maj-bevægelsen, der var inspireret af vestlige ideer, og særligt John Deweys social-pragmatiske ideer fik stor betydning for deres ønske om social, politisk og uddannelsesmæssig reform i retning af indførelse af videnskab og demokrati (op.cit.268). Et moderne skolesystem blev indført i 1920'erne, og tanken var at sætte „barnet i centrum“. ${ }^{5}$ Målet med de uddannelsesmæssige reformer var at skabe en skole, hvor barnet kunne opføre sig som et barn, ikke en „lille voksen“. Undervisningen skulle ikke længere kun baseres på udenadslære, men i højere grad på videnskabelige eksperimenter og dialog imellem lærer og elev. Desuden blev der indført frikvarter, hvor barnet kunne lege ${ }^{6}$ (op.cit.271).

Der er altså en parallel imellem forsøget på reform af uddannelsessystemet i starten af det 20. århundrede, hvor man gjorde op med den konfucianistiske 
fokusering på at recitere klassikerne, og det nuværende forsøg på at indføre kvalitetsopbyggende uddannelse og dermed gøre op med uddannelse, der har som primært formål at bestå eksaminer. Deweys demokratiske idealer er dog ikke så let forenelige med det autoritære kinesiske styresystem, og de kinesiske uddannelsesreformister formulerede deres ideer inden for suzhi-terminologien som kvalitetsopbyggende uddannelse. Ifølge Andrew Kipnis er suzhi et helligt slogan på linje med tidligere tiders Mao-slogans, og forskelligartede kinesiske politiske reformer udføres med henvisning til dette begreb (Kipnis 2006:298). Derfor er det ikke tilfældigt, at netop et forsøg på reform af uddannelsessystemet gøres med henvisning til begrebet „kvalitet“. Måske er dette medvirkende til, at reformen i vid udstrækning er modsætningsfyldt.

\section{Kvalitetsopbyggende uddannelse i praksis}

På trods af diverse forsøg på at reformere det kinesiske uddannelsessystem i retning af „,kvalitetsopbyggende uddannelse“ er hverdagen for kinesiske studerende præget af massiv konkurrence og omfattende eksaminer. Studerende ved Beijing Universitetet og Tsinghua Universitetet er de dygtigste i hele Kina, eller i hvert fald de studerende fra samtlige Kinas provinser, der har fået de højeste karakterer i den landsdækkende optagelsesprøve. De er altså sluppet igennem nåleøjet og er et sted, hvor millioner af unge kineser kun kan drømme sig hen. Imidlertid er de ofte stressede og deprimerede, og selv om der ikke findes tilgængelige statistikker på området, er det en udbredt opfattelse, at selvmordsraten blandt elitestuderende er højere end blandt studerende fra mindre prestigefyldte universiteter (Mooney 2005:1).

De beskriver ofte deres liv som en monoton bevægelse fra sovesal til klasseværelse til spisesal til klasseværelse til bibliotek til sovesal. De studerende forlader sjældent campus, og ofte, når jeg mødtes med studerende, gav de udtryk for, at de satte pris på at have tid til at reflektere lidt over deres liv. Det er en temmelig udbredt opfattelse hos både lærere, forældre og studerende, at ,kvalitetsopbyggende uddannelse" er umulig at indføre i praksis, medmindre hele uddannelsessystemet bliver ændret, for eksaminer er uomgængelige for at komme op til det næste trin. Jia Ling, der er underviser på Tsinghua Universitetet, forklarer, at hun gerne ville bruge mere tid i sin engelskundervisning på at anvende det engelske sprog og samtidig at tale om ting, der har betydning for de studerendes liv og for deres personlige udvikling, såsom familierelationer, fremtiden, ægteskab og jobmuligheder, men hun bliver samtidig nødt til at forholde sig til, at der er et helt strengt pensum, hendes elever skal igennem for at klare sig godt til eksamen. Med andre ord, hvis hun afviger ret meget fra den slagne vej og forsøger 
på en tilgang til uddannelse, der minder mere om „kvalitetsopbyggende uddannelse", risikerer hun i sidste ende at svigte sine elever.

Antropologen Rachel Murphy, der har studeret implementeringen af kvalitetsopbyggende uddannelse i grundskoler i Rivercounty, viser, at folks reaktioner på reformerne ofte er modsætningsfyldte, og hermed refererer hun til, at bønderne samtidig afviste reformerne og internaliserede dem (Murphy 2004:19). Noget lignende gør sig gældende hos mine informanter. Selv om der er stor utilfredshed med eksamenssystemets prioritering af udenadslære, giver de studerende, forældre og undervisere ofte udtryk for, at det er et nødvendigt onde, da det er det mest retfærdige. Nogle studerende udtrykker bekymring for, at det uklare begreb kvalitetsopbygning kan danne en bagvej for korruption. Lu Gang, en jurastuderende ved Beijing Universitetet, hvis forældre er bønder i Guangxi-provinsen formulerede det således: „Hvordan skal det afgøres, hvilke andre kompetencer end de strengt boglige der bør honoreres og være adgangsgivende? Hvem skal kontrollere dette? Somme tider bliver et talent opfundet, hvis der er nok penge på bordet." Han mente, at de nationale optagelsesprøver er mere „demokratiske“, i betydningen „retfærdige“. I praksis betyder „kvalitetsopbyggende uddannelse“, at en lille procentdel af de studerende ved disse to eliteuniversiteter optages på særlige vilkår, uden at de har skullet tage del i den landsdækkende optagelsesprøve. Disse studerende har for eksempel vundet en pris i en af de nationale konkurrencer og har udvist et scerligt talent inden for engelsk, fysik etc. Andre bliver optaget, fordi de har et særligt musikalsk eller sportsligt talent.

Samtidig med at studerende som Lu Gang afviser ,suzhi jiaoyu“ som delvist en tom floskel og delvist som uretfærdig, internaliserer han også i nogen grad ideerne bag kvalitetsopbyggende uddannelse, og det giver sig udslag i en følelse af underlegenhed. Lu Gang forklarede forskellen imellem studerende fra Beijing og studerende som han selv, der kommer fra fattigere dele af Kina:

Studerende fra Beijing er mere åbne ... mere vant til et moderne liv, til internettet, moderne restauranter, de kan male og danse, måske spille et instrument. Men vi studerende fra landet har ikke haft adgang til den slags ting, så der er et skel imellem land og by. Studerende fra byen ser ned på os, de synes, at de har en mere moderne indstilling, mens vi mangler kvalitet. Derfor har vi dårlig selvtillid, vi bor i en moderne by, men vi kommer fra mindre udviklede områder.

Det dannelsesprojekt, der er indbygget i ,kvalitetsopbyggende uddannelse“, fremføres også med henvisning til et ønske om at forhindre selvmord og psykiske problemer hos unge, hvis psykologiske kvalitet (xinli suzhi) er lav. ${ }^{9}$ Eksempelvis offentliggøres eksamensresultater ikke længere. En psykolog ved Tsinghua Universitetet forklarede det således: 
Disse unge mennesker, der næsten alle er enebørn bliver ofte refereret til som små kejsere og små kejserinder fordi de er forkælede materielt set men samtidigt er de ofte psykisk skrøbelige. De er meget intelligente men de mangler ... 'psykologisk kvalitet' [xin li suzhi]. Det kan ofte være svært for unge mennesker, der er vant til at være de dygtigste i de gymnasier de kommer fra, pludselig at være iblandt andre, der er dygtigere end dem selv. De er ikke vandt til at kommunikere med andre og føler sig ensomme.

Hendes udtalelse peger på en strukturel lighed mellem enebørn, der er blevet forkælet i familien, og som har svært ved at håndtere nederlag i skolen, og herefter elitestuderende, der er vant til at være de bedste i deres skoler, og som så har svært ved at håndtere modgang i konkurrencen med andre elitestuderende, når de når til universitetet.

Lad os vende os mod artiklens anden hovedperson, Gu Wei.

\section{Gu Wei}

Gu Wei forklarede betydningen af „kvalitetsopbyggende uddannelse“ således:

Jeg tror, Tsinghua og Beijing Universiteterne er meget bedre end de fleste kinesiske universiteter i den henseende. Der er et godt miljø for udvikling af menneskelige kompetencer generelt, men på trods af det kan man ikke komme uden om, at der er mange eksaminer. Lad mig sige det sådan ...tag for eksempel Harvard Universitet. Når studerende bliver færdige derfra, ved de, at de kan finde et godt job, så de kan fokuserer mere på at udvikle sig selv [ziji fazhan]. Jeg mener såsom, hvordan man kommunikerer med andre mennesker, lærer nye ting, såsom hvordan man skal lede andre. Det handler ikke om karakterer, men om en selv ... kvaliteten ... måske har du det ikke i udgangspunktet, men det er noget, der kan udvikles.

Som studerende i økonomi ved Tsinghua Universitetet er Gu Wei en af de 200, der blandt 20.000 andre ansøgere fra Hunan-provinsen i det sydøstlige Kina er blevet optaget. Ikke desto mindre var Gu Wei dybt ulykkelig, da jeg mødte ham i vinteren $2006 \mathrm{i}$ et af de mange store cafeterier på campus. Han så umiddelbart yngre ud end sine 23 år, var spinkelt bygget og havde tics i det ene øje. Gu Wei fortalte, at da han så mit opslag på universitetets intranet, så han det som en mulighed for at forsøge at tale med en udlænding og dermed udvikle sig selv (fazhan ziji). Imens vi sad over for hinanden på hver vores orange plastikstol og drak jasminte $i$ et af universitetets store cafeterier, kredsede samtalen sig om forholdet til hans mor. ${ }^{7}$

Min mor plejede at planlægge mit liv. Hun er en typisk kinesisk mor. Hun valgte, hvilken grundskole jeg skulle gå i, hvilket gymnasium jeg skulle gå på, og hun ønskede, at jeg skulle blive optaget på Tsinghua Universitetet. Som barn var hun 
altid meget striks over for mig. Hun opfordrede mig til at studere og syntes ikke, at jeg skulle spilde tiden med at lege, og jeg fulgte mere eller mindre hendes anvisninger. Jeg klarede mig godt til optagelsesprøverne til universitetet og jeg blev optaget på Tsinghua.

$\mathrm{Gu}$ Wei fortsatte med at forklare, at han ikke for alvor var interesseret i sit hovedfag, automation. Han vidste ikke rigtig, hvad han var interesseret i. Men hans mor blev meget lykkelig, da han blev optaget på Tsinghua. Selv blev han mest lettet. Men herefter ønskede hans mor, som så mange andre, at han skulle læse en master i USA, gerne ved et berømt amerikansk universitet.

$\mathrm{Gu}$ Wei forsøgte at leve op til denne forventning, men han var især dårlig til engelsk og kunne efter gentagne forsøg ikke bestå den nødvendige engelskprøve. Han fik hovedpine og led af søvnløshed, og han beskrev over for mig, hvordan han lå vågen om natten og så engelske sætninger flyve omkring i værelset. Han havde endog overvejet at tage sit eget liv, men han ville aldrig kunne gøre det på grund af sine forældre, sagde han. „De har ofret alt for mig, og hvem ville så skulle forsørge dem, når de bliver gamle?", 8 sagde han og refererede til, at de har arbejdet hårdt for at spare penge op til hans dyre universitetsuddannelse, men også at de ser ham med mulighed for at blive til noget stort, en chance, de ikke selv havde, da de var unge. Hans far tilhører den generation, der fik en akademisk uddannelse i en relativt høj alder, efter at Deng genåbnede optagelsesprøver til universiteterne. Han er medlem af partiet og arbejder som inspektør i industrien. Han har altid haft travlt med arbejde og har været fraværende i Gu Weis opvækst. Gu Weis mor har en teknisk uddannelse og arbejder med regnskaber. Gu Wei følte ikke, at han var i stand dele sine bekymringer med sine klassekammerater, da han mest af alt opfattede dem som konkurrenter. Han boede på værelse med tre andre drenge fra andre fag, men syntes heller ikke, at han kunne tale med dem. Han forstod dem ikke, sagde han. De tilbragte deres tid om aftenen med at spille computerspil. På et tidspunkt søgte han hjælp ved det psykologiske rådgivningscenter på Tsinghua, som havde hjulpet ham med at få udsat nogle af sine eksaminer og forsøgte at hjælpe ham til at udvikle sin psykologiske kvalitet.

Da jeg spurgte ham, hvordan hans mor havde reageret på, at han ikke var i stand til at komme til USA, svarede han, at hun til hans overraskelse havde været meget forstående. Hun havde sagt til ham, at ingen kunne bebrejde ham, at han havde gjort sit bedste. Det blev klart for ham, at det pres og de høje forventninger, han havde ligget under for som barn, ikke skyldtes manglende kærlighed, men at hun ganske enkelt ikke følte, at hun havde noget valg.

Der er så mange mennesker i Kina, at regeringen [zhengfu] ... undskyld, jeg mener forældrene [fumu] ... føler, at hvis ikke man klarer sig godt i uddannelsessystemet, har man ingen fremtid. 
I modsætning til Xiao Piao, der tilsyneladende ikke havde nogen distance til sine forældres krav og forventninger, havde Gu Wei gennemgået en krise, hvori han blev opmærksom på, at hans mor slet ikke var så kompromisløs, som han havde troet, men at hun havde følt, at hun ikke havde andet valg.

I løbet af foråret 2007 mødtes jeg af og til med Gu Wei, og jeg fik et indblik i hans måde at forøge at komme igennem sin krise på, eller med hans egne ord, hans bestræbelse på at „udvikle sig selv“ (fazhan ziji). „At vælge at mødes med dig er faktisk en form for „kvalitetsopbyggende uddannelse“, sagde Gu Wei. Jeg mindes tydeligt, hvordan Gu Wei sad over for mig en eftermiddag og holdt akavet på kniv og gaffel frem for de vante spisepinde, da vi en dag på hans initiativ mødtes til frokost på en „,vestlig“ café. Han forklarede, at „kvalitetsopbyggende uddannelse" gik ud på at blive bedre til at kommunikere med andre mennesker og at turde tage chancer. Han ville gerne udvide sin horisont og prøve noget nyt. I de samtaler, han havde haft med en psykolog, var han desuden blevet rådet til at fokusere på andet end sine studier for at blive mere selvsikker og for at udvikle sin psykologiske kvalitet (xinli suzhi). Derfor havde han besluttet sig for at begynde at gå til klavertimer, men til sin skuffelse havde han opdaget, at også sådanne kurser også var omgærdet af konkurrence. „Flere hundrede studerende ville gerne have klavertimer, men kun 30 kunne få lov", sagde han. Dette eksempel peger på, at manglen ikke skal placeres i det indre, men at et strukturelt forhold gør sig gældende her. Ideen om at udvikle kreative kompetencer udgør altså ikke et alternativ til testbaseret uddannelse, i og med vejen hertil også er omgærdet af konkurrence.

Gu Wei havde også taget et kursus, som han betragtede som en form for „,kvalitetsopbyggende uddannelse". Han oplevede imidlertid kurset som værende spild af tid. Kurset hed „Værdsættelsen af berømte udenlandske universiteter“, og det handlede om berømte amerikanske og britiske universiteter. På kurset blev der vist film fra disse universiteter, og selv om han godt kunne lide at drømme sig til Harvards smukke solbeskinnede campus, hvor luften var klar og blå, og de studerende så ud til at have tid og overskud til at sidde $\mathrm{i}$ grupper og grine sammen $\mathrm{i}$ græsset, mente han ikke, at han fik noget ud af kurset. Han ville gerne have været til USA og læse, men dette kursus føltes næsten som at få hældt salt i såret, og han blev mere deprimeret af det, sagde han.

Gu Wei sagde, at han godt kunne forstå dem, der valgte at tage livet af sig selv.

Det er håbløst. [...] I gymnasiet plejede vi at spørge os selv, hvorfor vi gik i skole, når det at gå i skole var lig med lidelse. Men lidelse er nødvendig for at få et bedre liv. Jo mere du lider, desto mere kan du vinde i fremtiden. Men efter jeg kom på universitetet, opdagede jeg, at det ikke nødvendigvis er rigtigt. I nogle tilfælde arbejder de dygtigste studerende mindst. De har en høj IQ og kan endda bruge tid på at spille computerspil. Det kan jeg umuligt gøre. Jeg studerede konstant og 
havde ingen fritid. Når jeg bliver færdig med min uddannelse, kan det godt være, at jeg kommer til at tjene en masse penge, men jeg vil stadigvæk ikke have nogen fritid. En revisor arbejder 20 timer om dagen. Kun døden er en udvej.

\section{Konklusion}

De kinesiske enebørn er blevet kaldt „små kejsere“, fordi deres forældre forkæler dem, ligesom det kejserlige hof forkælede sine kejsere. Men de kinesiske kejsere havde pligt til at bringe ære og rigdom til riget i midten, og dette gælder også for etbarnspolitikkens små kejsere, der må bære en tung byrde på deres skuldre (Fong 2004:30). Det er en udbredt opfattelse i Kina, at uddannelsessystemet er mangelfuldt, og at der hviler for stort et pres på unge menneskers skuldre, og denne tanke vinder genklang helt oppe i partitoppen. Med forsøget på at reformere uddannelsessystemet er hensigten at skabe kinesiske unge mennesker af høj kvalitet, der har de samme kvaliteter, som man forestiller sig amerikanske unge har, men som dog stadig er disciplinerede og loyale over for forældre og stat.

Set fra unge kineseres perspektiv, for eksempel Xiao Piao og Gu Wei, suppleres presset om at bestå eksaminer altså med mere eller mindre tomme krav om, at man skal „udvikle sig selv“ på andre måder ud over de rent boglige for at blive anset for at være en person af høj kvalitet eller dannelse. Med forsøget på at indføre „kvalitetsopbyggende uddannelse“ gør man således et strukturelt samfundsmæssigt problem til et indre problem, en indre mangel hos nogle studerende, der kan udvikles og fremmes gennem supplerende dannelseskurser og terapi.

Det er dog uomtvisteligt, at eksaminer stadig er en uomgængelig vej til social opstigning, og som Gu Weis forsøg på at få klaverundervisning viste, fortsætter konkurrencen også i andre sfærer. Gu Wei forestiller sig en fremtid, hvor konkurrence bliver ved med at være en uundgåelig del af livet, og sagde i et dramatisk øjeblik, at kun døden ville være en udvej. Hensigten med kvalitetsopbyggende uddannelse er at udvikle mennesker, så de realiserer deres „,fulde indre potentiale“ frem for blot at efterleve nogle ,sociale roller", men på grund af misforholdet imellem befolkningens størrelse og egentlige muligheder opleves dette som en selvmodsigelse. Desuden er målet er stadig et stipendium til Harvard. Når børn som Xiao Piao tvinges til klaver, engelskundervisning eller kalligrafitimer af deres forældre, eller universiteterne udbyder særlige „kvalitetsopbyggende“ kurser, såsom et kursus om berømte universiteter, har det karakter af en slags tom efterligning af form frem for indhold. Som om kreativitet kunne påfyldes individerne ligesom anden form for (parat)viden. Ligesom plagiering af eksamensopgaver er udbredt de studerende imellem, som det fremgik af historien om Xiao Piao, virker eksempelvis udbuddet af kurser om berømte udenlandske universiteter som en form for institutionaliseret efterligning. Som det fremgår af historierne om Xiao 
Piao og Gu Wei, er drømmen om Harvard roden til de unges problemer, i og med de er ude af stand til at opnå et stipendium til Harvard, men Harvard fremføres også som en del af problemets løsning. Her er der tale om en slags kortslutning, hvor mål og midler tilsyneladende blandes sammen. Kvalitetsopbyggende uddannelse har med andre ord på en og samme tid har til hensigt at nedbringe og at forøge konkurrencen. Flere af de studerende pegede også på den selvmodsigelse, at reformen fremføres ud fra et ønske om at nedbringe konkurrencen, men også med henvisning til et ønske om at opnå en kinesisk nobelprismodtager

\section{Noter}

1. Ifølge Andrew Kipnis benytter regeringskadrer begrebet til at retfærdiggøre deres magtudøvelse over for bønderne omkring sig, og alle former for udviklingsprojekter udføres med reference til, at det vil hæve befolkningen kvalitet (Kipnis 2006:296).

2. Mao er ofte blevet citeret for, at socialisme skulle ,give dem, der modtager en uddannelse, mulighed for at udvikle sig moralsk, intellektuelt og fysisk og at blive kultiverede arbejdere med en høj grad af socialistisk bevidsthed“ (Kipnis 2006:307).

3. Ifølge Tamara Jacka foretrækker de imidlertid selv at bruge begrebet „wenhua“ (kultur), da begrebet suzhi ofte stigmatiserer dem (Jacka 2005).

4. Det kinesiske begreb ,guan“ betyder både at disciplinere, opdrage og regere. Samtidig betyder det også at kere sig om. Det refererer altså både til forældres opdragelse af deres børn og til en regerings eller stats regering af et land. Der er en vis lighed imellem det kinesiske begreb „guan“ og Foucaults begreb ,governmentality“. En anelse paranoidt betragtede Foucault fængsler og skoler som parallelle institutioner, der begge har som formål at underlægge individer statens disciplinering og kontrol (Foucault 1977). Fængsler er steder for folk, der ikke har udviklet nok selvdisciplin til at indordne sig i samfundet og derfor må disciplineres via statens tvang. Skoler er derimod steder, hvor unge mennesker kan bevise, at de har selvdisciplin nok til at blive gode samfundsborgere, og de kan gøre sig håb om at blive del af en højtuddannet elite, der kan være med til at modernisere Kina (Fong 2006:116). Kinesiske studerende, undervisere og forældre er gennemgående enige om, at disciplin er det allermest afgørende for at klare sig i uddannelsessystemet. Det kræver en høj grad af selvdisciplin at undvære fritidsaktiviteter og at bruge det meste af sin tid på udenadslære og at øve sig på at løse en bestemt form for opgaver, der er udformet som de eksamensspørgsmål, man står over for. Vanessa Fong gengiver følgende udveksling imellem far og datter: „Forestil dig, at du er kommet i fængsel“, rådede Xun Jins far hende, da hun startede i gymnasiet $i$ året op til optagelsesprøven til universitetet. „Fra nu af må du udelukkende fokusere på dine studier. Som en indsat har du ingen frihed til at have det sjovt. Dit håb ligger i at bestå optagelsesprøven, som vil afgøre, om resten af dit liv er præget af lykke eller lidelse (Fong 2004:115).

5. John Dewey (1964) var den første moderne vestlige tænker, der besøgte og forelæste i Kina, blandt andet ved Beijing Universitetet. Dewey blev tildelt den såkaldte „Anden Konfucius Pris“ i 1920. Her bruges ordet konfucius ikke i den betydning, at Deweys tanker er lig Konfucius', men blot at han var en lige så stor tænker som Konfucius. Blandt andet Deweys ideer om demokrati og videnskab fik kinesiske intellektuelle til at sætte spørgsmålstegn ved den hierarkiske samfundsstruktur: hersker/masserne, far/øvrige familiemedlemmer, mand/kvinde, lærer/elev osv. (Qi 2006:258).

6. De kinesiske intellektuelles kamp for reform af det kinesiske sprog bar frugt, således at Uddannelsesministeriet i 1921 afskaffede ,wen yan wen“ (det elitære konfucianistiske skriftsprog) i 
skolerne og i stedet indførte „bai hua“ (et simplificeret skrift- og talesprog, der blev det nationale sprog) (Qi 2006:267).

7. Gu Wei talte meget lidt om sin far, men da jeg spurgte til ham, sagde han, at han altid havde arbejdet meget og dermed været meget lidt hjemme, så hans mor havde taget sig af hans opdragelse. Det er et gennemgående træk hos mine informanter. Ifølge Theresa Kuan er det kinesiske udtryk ,streng far, forstående mor“ blevet omvendt i reformperioden til ,streng mor, forstående far", da mødre nu både er på arbejdsmarkedet og har ansvar for deres barns uddannelse. Dermed er de under et voldsomt pres (Kuan 2008:82).

8. Markedsreformerne betyder også, at der ikke længere findes et socialt sikkerhedssystem, der varetager sundhed, uddannelse, pension osv. Der er derfor et stort pres på en generation af enebørn om at kunne leve op til generationskontrakten, altså at et barn i fremtiden skal kunne forsørge et forældrepar, og dette hænger også sammen med ideen om, at en høj uddannelse er nødvendig for at opnå et velbetalt job, som muliggør en omvending af generationskontrakten i fremtiden. Ved at genoplive de konfucianistiske dyder om ,sønnens pligt“, der blev angrebet i Mao-tiden, forsøger den kinesiske stat via uddannelsessystemet at opdrage unge mennesker til at have denne følelse af ansvar over for deres forældre (Kipnis 2009:214-15). Ifølge en af mine informanter lærer kinesiske folkeskolebørn at respektere deres forældre, ligesom de skal respektere „bedstefar Hu“ (præsident Hu Jintao).

Nøgleord: Kina, ungdom, uddannelsesreform, etbarnspolitikken, befolkningskvalitet, familie.

\section{Litteratur}

Anagnost, Ann

2004 The Corporeal Politics of Quality (Suzhi). Public Culture 16(2):198-208.

Bourdieu, Pierre

1984 [1979] Distinction: A Social Critique of the Judgement of Taste. London: Routledge \& Kegan Paul.

Cherrington, Ruth

1997 Deng's Generation: Young Intellectuals in 1980s China. London: Macmillan Press Ltd.

Dewey, John

1964 On Education: Selected Writings. Chicago Press.

Fong, Vanessa L.

2004 Only Hope: Coming of Age under China's One-Child Policy. Stanford: Stanford University Press.

Foucault, Michel

1977 Discipline and Punish: The Birth of the Prison. New York: Pantheon Books.

Girard, René

1965 Deceit, Desire and the Novel: Self and Other in Literary Structure. Baltimore: John Hopkins University Press.

Greenhalgh, Susan

2003 Planned Births, Unplanned Persons in: "Population" in the Making of Chinese Modernity. American Ethnologist 2:196-215. 
Huang, Quanyu

2001 Quality Education. Guangzhou, Guangdang: Southern Chines Press.

Jacka, Tamara

2005 Sisters and Outsiders: Rural Women in Urban China. London: M.E. Sharpe.

Kipnis, Andrew

2006 Suzhi: A Keyword Approach. The China Quarterly 186:295-313.

2007 Neoliberalism Reified: Suzhi Discourse and the Tropes of Neoliberalism in the People's Republic of China. Journal of the Royal Anthropological Institute (N.S.) 13:383-400.

2009 Education and the Governing of Child Centred Relatedness. I: S. Brandtstädter \& G.D. Santos (eds.): Chinese Kinship: Contemporary Anthropological Perspectives. London: Routledge Contemporary China Series.

Kleinmann, Arthur, Jiao Biehl \& Byron Good

2007 Subjectivity: Ethnographic Investigations. Berkeley: University of California Press.

Kuan, Theresa

2008 Adjusting the Bonds of Love: Parenting, Expertise and Social Change in a Chinese City. Upubliceret ph.d.-afhandling (refereret efter aftale med forfatteren). University of Southern California.

Liu, Weihua \& Zhang Xinwu

$2000 \quad$ Harvard Girl Liu Yiting. Beijing: Zuoija Chubanshe.

Marcuse, Herbert

1972 [1968] Negations: Essays in Critical Theory. Harmondsworth: Penguin Books.

Milwertz, Cecilia

1997 Accepting Population Control. Richmond: Curzon Press.

Mooney, Paul

2005 Campus Life Proves Difficult for China's "Little Emperors". The Chronicle of Higher Education.

Murphy, Rachel

2004 Turning Peasants into Modern Chinese Citizens. The China Quarterly 177:1-20.

Qi, Jie

2008 A History of the Present: Chinese Intellectuals, Confucianism and Pragmatism.

I: T.S. Popkewitz (ed.): Inventing the Modern Self and John Dewey. New York:

Palgrave Macmillan.

Thøgersen, Stig

2002 A County of Culture: Twentieth Century China Seen from Village Schools of

Zhouping, Shandong. Ann Arbor: The University of Michigan Press.

Woronov, T.E

2007 Chinese Children, American Education: Globalizing Child Rearing in

Contemporary China. I: J. Cole \& D. Durham (eds.): Generations and

Globalization: Youth, Age and Family in the New World Economy.

Bloomington \& Indianapolis: Indiana University Press. 